\title{
Surgical management of large abdominal wall fibromatosis during pregnancy
}

\author{
Paul Anthony Sutton, ${ }^{1}$ Paul Rooney, ${ }^{1}$ Nasim Ali, $^{2}$ Coonoor R Chandrasekar ${ }^{3}$
}

${ }^{1}$ Royal Liverpool and Broadgreen University Hospitals NHS Trust, Liverpool, UK

${ }^{2}$ Clatterbridge Cancer Centre NHS Foundation Trust, Bebington, UK

${ }^{3}$ Trauma and Orthopaedic Department, Royal Liverpool and Broadgreen University Hospitals NHS Trust, Liverpool, UK

\section{Correspondence to}

Paul Anthony Sutton, paulsutton01@doctors.org.uk

Accepted 16 February 2019

\section{DESCRIPTION}

Aggressive abdominal wall fibromatosis is an uncommon tumour that has propensity for significant growth. Patients often present during pregnancy, with growth related to the associated hormonal changes having been described. ${ }^{1}$ In the majority of patients the condition can be managed conservatively, as regression on completion of the pregnancy may often occur. While surgery in pregnancy is to be avoided where possible, we present a case whereby rapid tumour growth, severe pain and breathlessness due to the large tumour mandated urgent surgery. In cases such as this, after failed

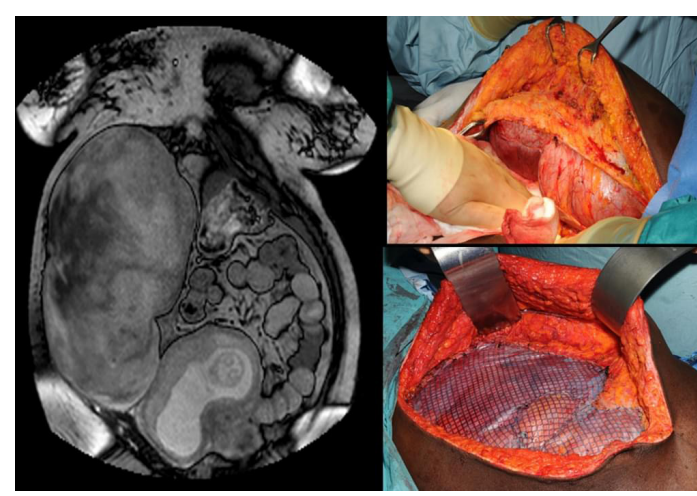

Figure 1 A patient with abdominal wall fibromatosis. The coronal section of an MRI scan performed during the second trimester is shown (left), as well as the wide dissection required to ensure complete tumour excision (top right) and the resulting abdominal wall reconstruction (bottom right).

\section{Learning points}

- Abdominal wall fibromatosis has a propensity for significant growth during pregnancy.

- Management requires multidisciplinary input from surgeons, physicians and obstetricians.

conservative management, any surgical treatment must ensure safety of the mother and the fetus, complete tumour excision and subsequent abdominal wall reconstruction. The images in figure 1 depict the coronal section of an MRI scan performed during the second trimester (left), the wide dissection required to ensure complete tumour excision (top right) and the resulting abdominal wall reconstruction (bottom right). The patient delivered a healthy boy 4 months after surgery by elective caesarean section.

Contributors PS, PR, NA and CC: conception, planning and conduct; editing and approval of final document. PS: initial draft.

Funding The authors have not declared a specific grant for this research from any funding agency in the public, commercial or not-for-profit sectors.

Competing interests None declared.

Patient consent for publication Obtained

Provenance and peer review Not commissioned; externally peer reviewed.

\section{REFERENCE}

1 Fiore M, Coppola S, Cannell AJ, et al. Desmoid-type fibromatosis and pregnancy: a multi-institutional analysis of recurrence and obstetric risk. Ann Surg 2014;259:973-8.

Copyright 2019 BMJ Publishing Group. All rights reserved. For permission to reuse any of this content visit

https://www.bmj.com/company/products-services/rights-and-licensing/permissions/

BMJ Case Report Fellows may re-use this article for personal use and teaching without any further permission.

Become a Fellow of BMJ Case Reports today and you can:

- Submit as many cases as you like

- Enjoy fast sympathetic peer review and rapid publication of accepted articles

- Access all the published articles

- Re-use any of the published material for personal use and teaching without further permission

Customer Service

If you have any further queries about your subscription, please contact our customer services team on +44 (0) 2071111105 or via email at support@bmj.com. 